\title{
Recently recognized chromosomal defects of clinical importance
}

\author{
Marcus Pembrey ${ }^{1}$ and Michael Baraitser ${ }^{2}$
}

${ }^{1}$ Senior Lecturer, Mothercare Unit of Paediatric Genetics, Institute of Child Health (University of London), 30 Guilford Street, London WC1N 2 NR and ${ }^{2}$ Consultant Clinical Geneticist, Hospital for Sick Children, Great Ormond Street, London WC1N 3JH, UK.

\begin{abstract}
Summary: We review those conditions which have recently been recognized to be associated with small, sometimes difficult to detect, chromosomal abnormalities. These include the Prader-Willi syndrome and $\mathrm{X}$-linked mental retardation.
\end{abstract}

\section{Introduction}

Edwards, Harnden, Cameron, Goss and Wolff (1960) described a new trisomic syndrome - which they attributed to a triplication of either chromosome 17 or 18 (later proven to be 18). Wolff, in that historic article, is the subject of this Festschrift and this review is dedicated to him in respect of his lifelong contribution to so many aspects of paediatrics. Only a few years before that publication, Lejeune (1959) had shown that Down's syndrome was linked to the presence of an extra chromosome - designated a G-group chromosome, and now as chromosome 21 . Trisomy 18 was followed by 13 (Patau et al., 1960, the next article in the same journal), and then a whole host of partial trisomies and deletions were described, some with recognizable phenotypes but others showing great diversity.

There was a major advance in 1970 with the development of banding by Caspersson et al. This led to easy recognition of individual chromosomes and an improvement in the detection of small deletions; 350 bands could be seen by conventional G-banding but it was obvious that there might be small deletions, too small to be visualized by routine methods. This was predicted by clinicians who had long suspected that amongst the dysmorphic patients with multiple malformation syndromes, including defects of the heart and mental retardation, known not to be inherited in a simple Mendelian fashion, there would be undetectable deletions.

In 1976, Yunis introduced the term 'high resolution' chromosome banding to describe a technique pioneered in his laboratory to advance visualization from the 350 band stage to 400 and beyond that to an 850 stage. Resolution has, even under exceptional circum-

Correspondence: M. Pembrey, M.D., F.R.C.P. stances, delineated 1000 bands. The techniques are expensive and time consuming but their greatest contribution might be to identify significant changes in the genome which can, retrospectively, be seen by conventional methods once an area of possible change is recognized.

Improvement in technology has to some extent blurred the clinical distinction between single gene defects and chromosomal abnormalities. Chromosomal abnormalities are generally regarded as those that can be observed by microscopy whereas single gene disorders are those with normal chromosomes in which the pattern of inheritance conforms to the well worked out Mendelian ratios. It is now realized that what might appear to be simple Mendelian inheritance can be found to be chromosomal in origin. Examples are given.

\section{Autosomal deletions}

\section{Aniridia}

In aniridia, the iris is rudimentary and the remnant may block the angle to cause glaucoma. The anterior chamber is shallow, resulting in contact between the cornea and lens. Vision is poor. The condition is known to be dominantly inherited in a number of families in which the defect is transmitted vertically from generation to generation. In this form, the chromosomal analysis is normal. However, there is also a known association of aniridia with Wilms' tumour (nephroblastoma) and in a number of these patients a deletion in the $11 \mathrm{p} 13$ region has been found (Francke et al., 1977) - that is, in the short arm of chromosome 11 near the centromere. There is also a 
suggestion that an $11 \mathrm{p}$ deletion can cause Wilms' tumour alone, especially when hemihypertrophy is present. In addition, there have been reports of patients with $11 \mathrm{p} 13$ deletions with aniridia alone (Ferrell \& Riccardi, 1981). It is here that high resolution banding becomes important. Nakagome and colleagues in 1984 looked retrospectively at 5 cases of aniridia/Wilms' tumour and all showed the characteristic change. However, it is not always easy to find - in one of these cases a small deletion was found in only half of the examined cells.

What seems to be emerging is a relationship between overlapping syndromes, dependent on the extent of the lesion. Perhaps just a single base change or tiny deletion at a particular locus in the genomic DNA can result in dominantly inherited aniridia. A slightly larger change, i.e. a small deletion in band p13, involves a tendency to develop Wilms' tumour or aniridia and if the deletion involves both regions then Wilms' tumour and aniridia might occur together.

A similar development has occurred in our understanding of retinoblastoma - although the situation is slightly more complicated.

\section{Retinoblastoma}

There is a parallel between the mechanism of development of Wilms' tumour and retinoblastoma (see below). Although most Wilms' tumours are sporadic and vertical transmission within families is rare, it has been shown (Orkin et al., 1984) that if a deletion occurs on one of the short arms of chromosome 11 at p13, then a second mutational event on the other chromosome 11, at the same place but in a somatic cell, could explain the development of Wilms' tumour in at least some patients.

Retinoblastoma is a tumour of childhood which occurs either unilaterally or bilaterally. Vogel (1979) suggested that $40 \%$ were hereditary and that this figure encompasses most of the bilateral tumours and $15-20 \%$ of the unilateral retinoblastomas. It is intriguing (see Johnson et al., 1982, for review) to find that $5 \%$ of retinoblastomas could be explained by what seemed to be a chromosomal deletion affecting band q14 of chromosome 13. These patients had bilateral tumours and the majority were mentally handicapped, albeit on occasions only mildly. This contrasted with those families in which bilateral retinoblastomas were transmitted from generation to generation - seemingly as an autosomal dominant trait - where intelligence was normal.

The condition, as in aniridia, can be caused by a submicroscopic change first thought to be a single gene defect but now thought to be a small deletion. The same end result occurs when there is a visible deletion in q14 of chromosome 13. However, for the retinoblastoma to occur, another mutation is neces- sary. This is a somatic mutation - an event which must occur commonly in somatic cell DNA. Two gene changes are therefore necessary and the tumour results from homozygosity at a given locus, i.e. by conventional nomenclature it is recessive. In sporadically occurring tumours, both mutations occur in somatic cells.

It therefore seems that a condition which was thought occasionally to be inherited as a dominant with reduced penetrance might be the result of a small chromosomal deletion - sometimes visible and sometimes not.

Further evidence for a small deletion, even though it cannot be seen, comes from experience with esteraseD. The gene coding for esterase-D has been localized to the same band as that known to be deficient in bilateral retinoblastoma. As each band represents many genes it is likely that these loci are at least closely situated in the same region. Arising from this has been the finding of patients with retinoblastoma, with normal chromosomes, in which the activity of esterase-D has been half normal suggesting that a presumptive deletion in the band q13 is present but is not visible by conventional banding techniques - not even by extended banding.

\section{Prader-Willi syndrome}

There are a number of conditions which are clinically recognizable but where the diagnosis rests on historyo and clinical observation. Special investigations to confirm a clinical impression are seldom helpful. This is a particularly difficult situation to deal with in those dysmorphic syndromes where variability of expression occurs. The Prader-Willi syndrome falls into the category of being easy to diagnose when typical

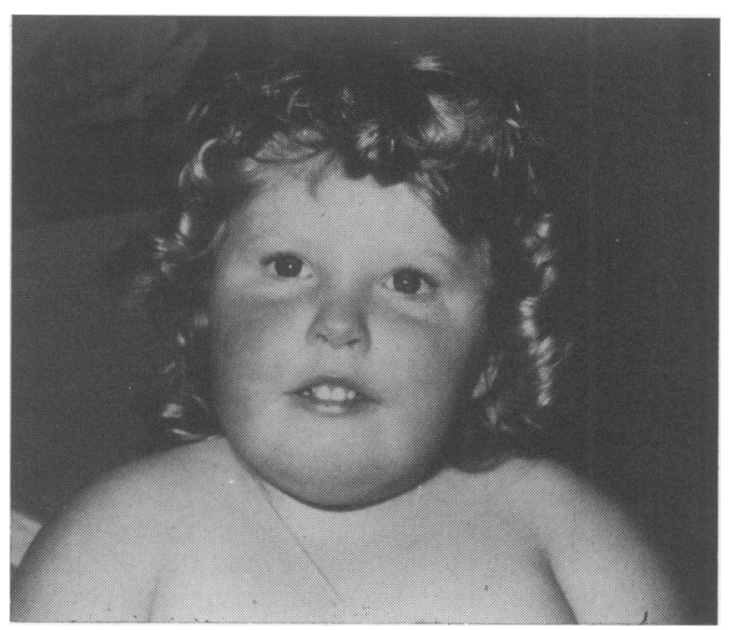

Figure 1 Prader-Willi syndrome. 
(Figure 1) but which can be under- or over-diagnosed. Characteristically there are early feeding difficulties, later (second year of life) hyperphagia and obesity, hypogonadism, microcephaly, almond shaped eyes, a tent-shaped mouth, and small hands and feet, but the syndrome is not always easy to diagnose. Ledbetter $e t$ al. (1981) suggested that the diagnosis could be confirmed in a proportion of patients by chromosome analysis. An interstitial deletion in the long arm of chromosome 15 involving a breakpoint at $15 q 13$ has been the most constant finding.

What of the half without obvious deletion? In these patients, the deletion might be too small to be seen, or there might be other conditions which mimic PraderWilli. Prader-Willi has led the way in the realization that it is possible that other known syndromes with multiple congenital malformations might turn out to be caused by a small deletion.

\section{Miller-Dieker syndrome (lissencephaly syndrome)}

The diagnosis is often suggested clinically by the presence of vertical wrinkling of the forehead in a microcephalic child but this is not invariably present. Severe retardation, seizures, early hypotonia, occasional congenital heart defects and even polydactyly have all been described. The inheritance was thought to be recessive and four, or possibly five, families were found to have more than one affected sib. However, Dobyns et al. (1983) found one patient to have a small deletion in the short arm of chromosome 17 . When the four previously reported families were re-examined, either balanced translocations or deletions were detectable in the $17 \mathrm{p} 13$ regions and the emphasis has now swung from simple Mendelian inheritance to a chromosomal abnormality and high resolution banding needs to be employed on all patients with clinical features of the lissencephaly syndrome (Dobyns et al., 1984).

\section{Langer-Giedion syndrome or tricho-rhino- phalangeal syndrome}

Tricho-rhino-phalangeal syndrome has been divided into two types. Type I is characterized by a thin upper lip, sparse hair, bulbous nose, rather minor phalangeal changes and cone shaped epiphyses. Type II, also called tricho-rhino-phalangeal syndrome with exostosis, differs from type I by the presence of microcephaly and mental retardation, redundant skin, especially in the neck and by bushy or-normal, rather than sparse, eyebrows. However, four new patients described by Langer et al. (1984) were not reported to be retarded and the distinction between type I and type II is not clearcut. They share in common the striking facial characteristics and the cone shaped epiphyses.

Type $I$ is clearly inherited as an autosomal dominant condition and three generation families have been reported. The inheritance is less clear for type II (i.e. Langer-Giedion syndrome). There has been a father/ daughter pair but nothing more extensive than that. It has, however, been suggested that because of the variability of the condition, the diagnosis in the offspring might have been missed, but this is unlikely.

It was then that a number of patients with type II were found to have a chromosomal abnormality. When reviewed by Langer et al. in 1984 there were at least 12 patients with a deletion of $8 \mathrm{q}$ involving either $8 \mathrm{q} 23$ or $8 \mathrm{q} 24$. High resolution banding (Bühler \& Malik, 1984), has narrowed down the breakpoint even further and these authors designate the common area to be q24.1. It is also of interest that a presumed type I patient (Hamers et al., 1983) has been found to have the deletion.

Clearly, these advances are leading to a better delineation of syndromes (both 'lumping' and 'splitting' will occur), and an improvement in diagnostic criteria for many syndromes must result.

\section{Other recognizable syndromes}

So many of the chromosomal abnormalities are not possible to diagnose clinically. This especially applies to the deletions - the main reason being that microscopically it can never be certain that two patients with a deletion at, say, band q14 of chromosome 11 have indeed lost the same amount of material. There are probably 'hot-spots' where breakage is more likely to occur, hence the similarities of patients with the cri-duchat, (5p-) syndrome. Where this tends to happen, small deletions can be detected because a shrewd clinician has suggested to the cytogeneticist that the syndrome would fit a specific deletion. The 4p- (Wolf Hirshhorn syndrome) is a good example. Typically, the children are retarded and severely microcephalic. They have a 'Greek helmet' facial appearance caused by the wide nasal bridge and parallel sides to the nose. This gives the nose a square, flat outline. The upper lip is thin, often cleft, and the philtrum short. Preauricular ear tags might be present. There have now been a number of cases on record where the initial chromosome investigation has been normal and only perseverance by a clinician and a re-examination of the chromosomes has enabled the diagnosis to be confirmed.

Following the same theme, 13q-syndrome might be suggested by small or absent thumbs, and in trisomy 8 , very deep palmar and plantar creases occur. In 9p trisomy, the hands are characteristic. The palms are long when compared to the length of the fingers and there is often an unusual little finger which is not only small but in which there is fusion of the two finger creases.

There are many other examples of almost unique 
clinical features which could suggest a diagnosis and there have even been attempts to localize certain dysmorphic features to specific sites on the chromosome. Diagnostically, this might not be vitally important - especially if all children with multiple handicap have a karyotype performed - but it might help to localize known syndromes to particular parts of the genome - an activity which is gaining ground amongst molecular geneticists in their endeavours to map the genome and thereby improve our prediction of genetic disease.

\section{Structural abnormalities of the $X$ chromosome - Fragile $\mathrm{X}$ syndrome}

The most dramatic change in the clinical application of cytogenetics in recent years has been the delineation of the fragile $\mathrm{X}$ syndrome, probably the commonest form of mental retardation in boys after Down's syndrome, and by no means an insignificant contribution to moderate mental retardation in females.

The disorder that is characterized by mental retardation and the presence of a fragile site - the appearance of an unstainable gap - near the tip of the long arm of the $\mathrm{X}$ chromosome at Xq27-8 has been given various names. The term Martin-Bell syndrome comes from the family described over $\mathbf{4 0}$ years ago (Martin \& Bell, 1943), in which several mentally retarded descendants have been shown to exhibit fragile sites, plus the associated features of macroorchidism and the characteristic facial appearance (Richards et al., 1981). Some of the names emphasizing the cytogenetic aspects, such as marker X mental retardation (Turner \& Jacobs, 1983) have now been superseded by the general term fragile $\mathrm{X}$ syndrome. There is some merit in the latter term being used as a general designation, with the name Martin-Bell syndrome limited to those family members exhibiting the full manifestations, for, as will be discussed later, not every man who transmits the condition is clinically affected.

The fragile $\mathrm{X}$ syndrome has been the subject of some recent reviews (Turner \& Jacobs, 1983; Sutherland, 1985) and the January 1984 issue, vol. 17, no. 1, of the American Journal of Medical Genetics reports the proceedings of the first international workshop on the subject plus 29 additional papers on X-linked mental retardation. The medical importance of the fragile $X$ syndrome stems from the fact that it is both a common cause of mental retardation and a model for a class of genetic mutations that are as yet ill defined, but seem to be neither the usual chromosomal abnormality, nor a single gene defect inherited in a regular Mendelian fashion. Overall, a third of female heterozygotes have intellectual impairment (Turner et al., 1980), and there is increasing evidence that what is initially transmitted within some families is a premutation that causes no phenotypic abnormality, but tends to generate the definitive mutation probably by a recombination event (Pembrey et al., 1985).

\section{Prevalence in patient populations with mental retardation and autism}

Indirect estimates of the general population frequency have been derived from studies on defined patient populations and it seems the prevalence is about 1 in 1500-2000 males (Turner \& Jacobs, 1983; Sherman et al., 1984; Bundey et al., 1985). Between 1 in 700 and 1 in 1000 females will carry the mutation, a third of whom will have mental impairment. The overall prevalence of the fragile $\mathrm{X}$ syndrome in males in institutions for the retarded ranges from 1.6\% (Sutherland, 1982) to $6 \%$ (Froster-Iskenius et al., 1983), but if known chromosomal and dysmorphic cases are excluded the figure rises to about $7-9 \%$ of males. In special schools catering for the moderately retarded the incidence was found to be $3.4 \%$ in males and $2.3 \%$ in females (Turner et al., 1980; Sutherland, 1985).

Prevalence studies in Sweden found that the fragile $\mathrm{X}$ syndrome accounted for $4.5 \%$ of boys with mild mental retardation (Blomquist et al., 1983); 7\% of boys with uncomplicated severe mental retardation (Blomquist et al., 1982) and $16 \%$ of 83 boys witb infantile autism (Blomquist et al., 1985).

This last observation is one of a number of reports (Brown et al., 1982; Gillberg, 1983; Levitas et al., 1983) pointing to an association between fragile $X$ syndrome and autism. Blomquist et al. (1985) report autistic brothers with 11-18\% fragile sites, one of whom had an IQ greater than 85 . Despite some negative reports (Venter et al., 1984), accumulated published experience points to a genuine biological cause for the association between fragile $\mathrm{X}$ and autism. However, the genetic contribution to infantile autism is itself complex, twin and family studies revealing an association between autism and cognitive disorders often characterized by problems with spoken language (Folstein \& Rutter, 1977). What contribution the fragile $X$ syndrome makes to the reported $2-3 \%$ sibling recurrence risk for infantile autism (Folstein \& Rutter, 1977) still has to be resolved, but it undoubted ly accounts for some sib pairs.

\section{The clinical picture of the Martin-Bell syndrome}

Until routine cytogenetic detection of the fragile site became possible (Sutherland, 1977) families with Martin-Bell syndrome (Martin \& Bell, 1943; Dunn et al., 1963) were regarded as having non-specific mental retardation with no particular distinguishing physical features. However, once the presence of the fragile $X$ became the definitive diagnostic test it has been 
possible to discern a fairly characteristic physical appearance which often allows the experienced clinician to predict the cytogenetic findings. Indeed, increasingly the shoe is on the other foot, with the clinician insisting that the patient has precisely the right combination of physical and behavioural characteristics, but with the cytogeneticist being unable to demonstrate the fragile site on the X. Fishburn et al. (1983) studying a cohort of males with X-linked mental retardation found 18 that had the characteristic features of the Martin-Bell syndrome, including macro-orchidism, but in 6 no fragile sites could be demonstrated. Whether or not such cases have a different mutation at the same gene locus cannot yet be answered.

\section{Macro-orchidism}

Nearly all post-pubertal affected males have large testes with a mean volume ranging from $15-127 \mathrm{ml}$ (normal range 18-25 $\mathrm{ml}$, depending on race) (Opitz \& Sutherland, 1984). However, clinical diagnostic problems often arise in the pre-pubertal males. Thake et al. (1985) studying boys with severe mental retardation found 6 out of 10 boys with fragile $\mathrm{X}$ syndrome (aged 10-16 years) had testicular volumes over the 90 th centile, whilst their 3 fragile $X$ boys under 10 years had volumes of 4,6 and $15 \mathrm{ml}$, all greater than $2 \mathrm{ml}$ which is regarded as the upper limit of normal for this age group. However, another study (Largo \& Schinzel, 1985) found $12 / 13$ boys aged 2.6 to 12.5 years had testes volumes less than $2 \mathrm{ml}$. The situation is complicated by the fact that large testes are commoner in mentally retarded males as a whole. Howard-Peebles \& Finley (1983) found that $8 \%$ of white males in a State mental institution had marked macro-orchidism (above $34 \mathrm{ml}$ ) but only $27 \%$ of these men were fragile site positive.

\section{Physical features}

The head circumference tends to be larger than normal, being greater than the 50th centile in about $75 \%$ of cases. In affected adult males Jacobs et al. (1983) found 4/9 and Meryash et al. (1984) 4/18 found head circumferences at the 97 th centile, or above.

The face tends to be long with a long nose, slight mid-face hypoplasia and prominent mandible (Figure 2). The ears are large, with the mean length significantly increased (Meryash et al., 1984) and are frequently anteverted and anteflexed. Submucous clefts, cleft uvula or palate may occur. These facial features are more common in adults with the Martin-Bell syndrome and may also occur in mentally retarded women.

Opitz et al. (1984) has drawn attention to what may be a generalized connective tissue dysplasia in the
Martin-Bell syndrome. There tends to be soft velvety laxed skin, and hypoplasia of ear cartilage.

\section{Neurological features}

The degree of mental retardation is variable but the mean IQ is in the 35-50 range and speech development appears disproportionately delayed. Pueschel \& Finelli (1985), studying 22 patients, found $82 \%$ had brisk deep tendon reflexes and $41 \%$ extensor plantar responses. Gaze eversion was observed in $77 \%$ and about half exhibited hyperactive behaviour; about half had some inco-ordination and a stooped posture and gait. Fryns et al. (1984) found 20/21 boys had hyperkinesis. Speech was delayed with 3 boys displaying no active verbal activity even after the age of 5 years. Echolalia and perseveration were found in 10/22. Largo \& Schinzel (1985) found similar developmental behaviour disturbances in 13 boys from 3 families. Language, and imitative and symbolic play were particularly retarded. About $15-25 \%$ have a history of grand mal seizures, which can usually be controlled by anti-convulsants.

\section{Criteria for cytogenetic investigation}

Despite the emergence of a fairly characteristic phenotype in adult life, in paediatric practice it can still be difficult to decide in whom the fragile $X$ should be sought. Thake et al. (1985) specifically addressed this problem using an appropriately ascertained sample of mentally retarded boys in a defined geographical area (Bundey et al., 1985). In their study any boy with severe 'idiopathic' mental retardation, regardless of his clinical features, was associated with a 1 in 9 chance of identifying a fragile site at Xq27-8. If boys with a head circumference over the 50th centile, testicular volume over the 50th centile (for boys over 10 years) and an IQ between 35 and 70, were selected then the chance of finding a fragile $X$ was 1 in 3.6. If an affected male had a similarly affected maternal male relative (other than his brother) the chance of finding fragile $X$ was 1 in 2.6. The yield was only slightly less if one took all those with a similarly affected brother. Some cytogenetic laboratories have changed to folate depleted medium for all routine lymphocyte cultures, which at least allows a retrospective search for fragile sites if requested.

\section{The fragile site at $\mathrm{Xq} 27-28$}

A fragile site is a region that has failed to condense normally at the onset of mitosis, so the metaphase chromosome exhibits a constriction, in the present case at Xq27-8. High resolution banding studies have located the fragile site to band Xq27.3 (Brookwell \& Turner, 1983). At least in vitro the linking strand is 

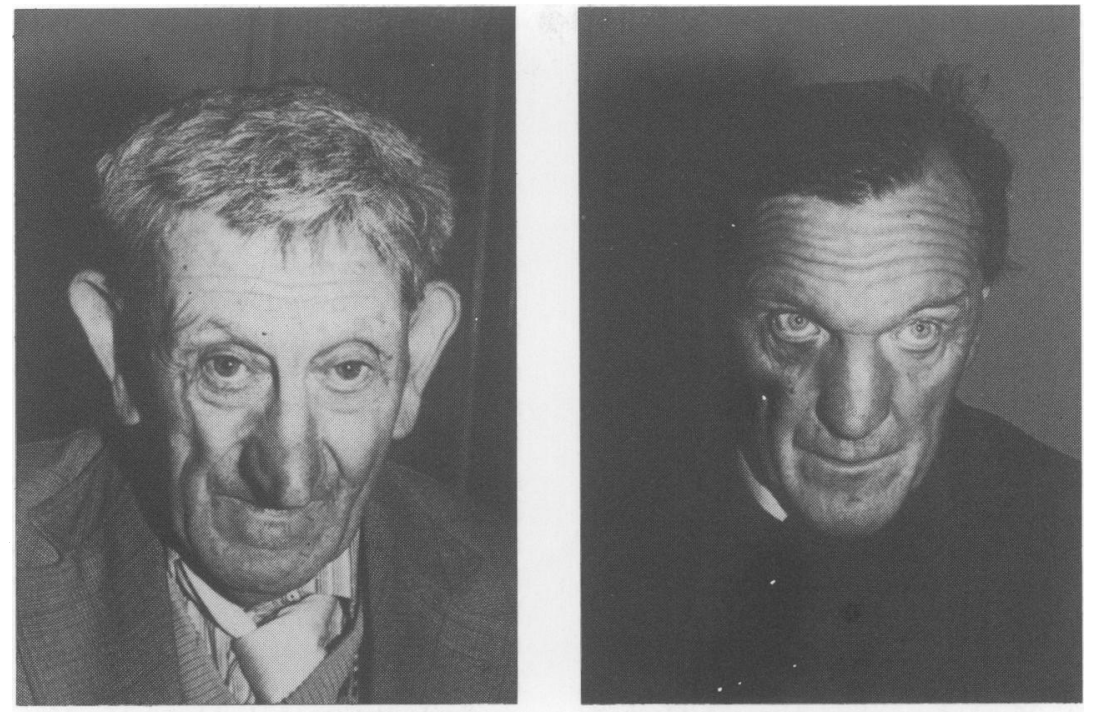

a

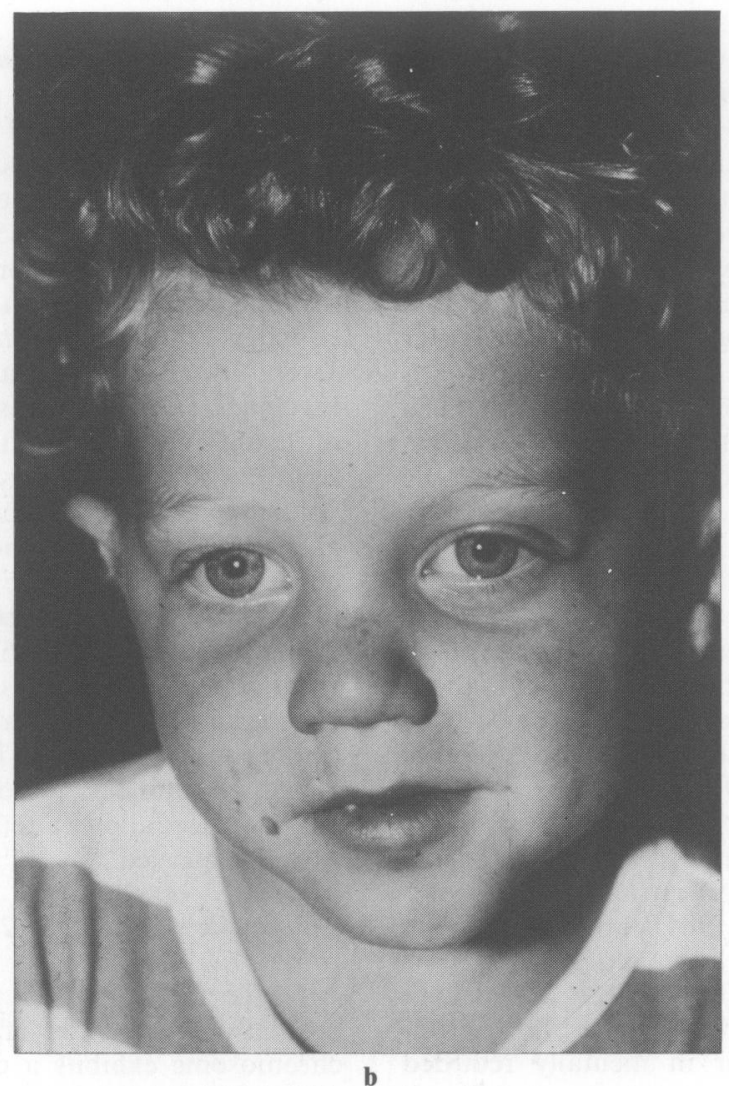

Figure 2 Fragile $X$ mental retardation. (a) Cousins from the original Martin-Bell pedigree showing typical facial features. (b) 3 year old boy who, apart from a relatively large head, has few dysmorphic features. 
liable to break so that cells with a deletion of the tip of the long arm of the X can occur (Fitchett \& Seabright, 1984) as well as those in which a single chromatid has broken away (Figure 3).

Typically $5-50 \%$ of the lymphocytes of an affected male show fragile sites. There is no explanation for why some cells of the same tissue do not express fragile sites. A fragile site probably represents defective DNA synthesis during the DNA replication that precedes mitosis, and perhaps variation in the length of the cell cycle thereafter allows some cells to complete DNA replication before the chromosomes condense.

At least one hamster/human somatic cell hybrid line was shown to express the fragile site in the absence of human autosomes (Nussbaum et al., 1983), but it is by no means clear what all the factors necessary for fragile site expression are. Although the percentage of lymphocytes expressing fragile sites in affected males varies widely both between and, to a lesser extent (Soudek et al., 1984), within families, any one individual maintains a fairly constant level of fragile sites. Sutherland (1977) first showed that the expression of the fragile $X$ is folate sensitive, being seen in lymphocytes that are cultured in media free of folic acid and thymidine. They can be induced by inhibitors of folate metabolism such as methotrexate and inhibitors of thymidylate synthetase such as FUdR and FCdR (Glover, 1983). Fragile sites can be induced with difficulty in fibroblasts and amniocytes, usually using methotrexate or FUdR, but unfortunately these methods are too unreliable for prenatal diagnosis. Preliminary data (Tommerup et al., 1985) suggest that it is possible to use trophoblast cell cultures obtained by chorionic villus sampling for prenatal diagnosis, and this is likely to replace fetal bloodsampling as the prenatal diagnostic test of choice, although fetal lymphocyte analysis will always represent a valuable backup. It is not known what the nature of the fragile site is at the DNA level. Sutherland (1985) has recently observed that excess of thymidine, but not its analogue $\mathrm{BrdU}$, will induce the folate sensitive fragile sites and concludes that the critical factor involved in their expression is the $\mathrm{dCTP} / \mathrm{dTTP}$ ratio during DNA synthesis. He goes on to hypothesize that if either dTTP or ACTP was limited, single strand gaps would arise during DNA replication if the DNA sequence involved was an alternating polypurine/ polypyrimidine structure such as (AGAGAG) $n_{1}$ (TCTCTC) $n_{2}$.

\section{Cytogenetic/clinical correlations}

Although it is natural to look for clinical correlations, there is no logical reason to suppose that there should be any relationship between the percentage of lymphocytes with fragile sites in an in vitro test and a

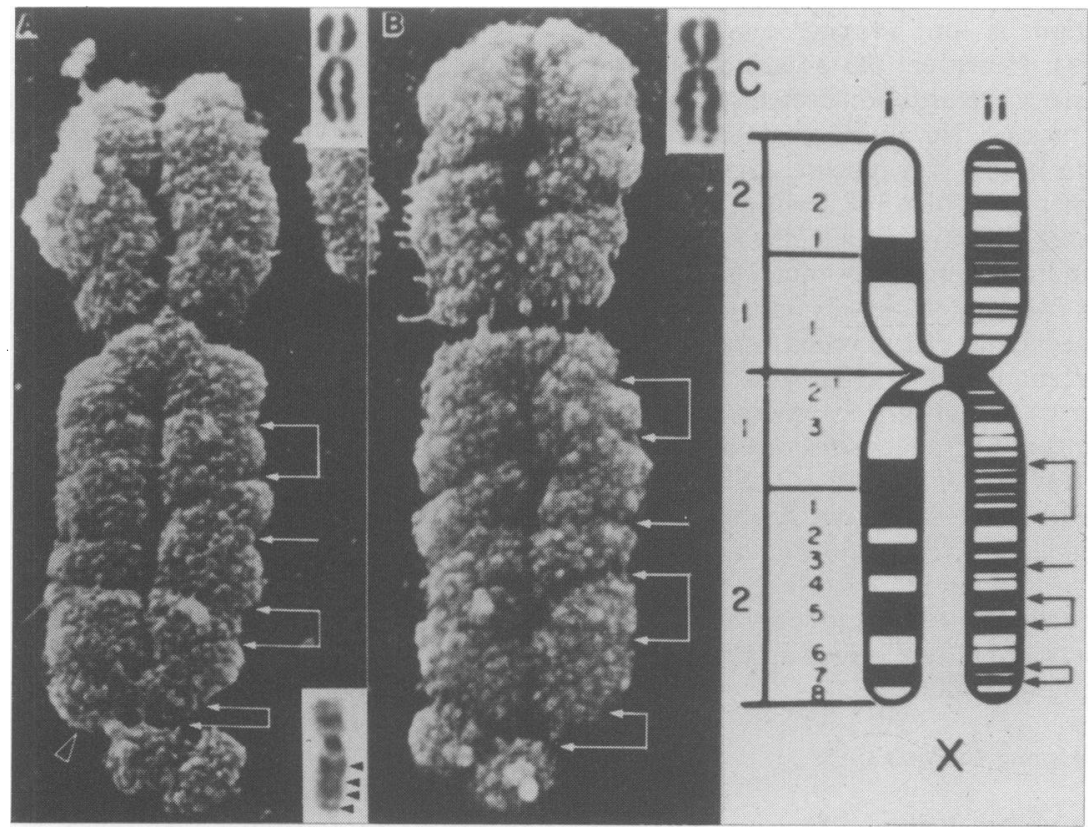

Figure 3 Two G-banded fragile $X$ chromosomes viewed by scanning electron microscopy, showing the gap towards the distal ends of the long arms. The diagrammatic representation shows the bands viewed by light microscopy (chromatid i) and the bands viewed in prometaphase banding (chromatid ii). 
clinical feature such as brain development. Clearly the presence or absence of any fragile sites is likely to be biologically meaningful, but other correlations, with age for example (Sherman et al., 1984), may turn out to be spurious, being generated by ascertainment bias and the pooling of results from individuals in whom the genetic mutations are at different stages of evolution (Turner \& Jacobs, 1983; Pembrey et al., 1985).

Males Because many cytogenetics laboratories are now routinely using folate depleted medium, relatively large numbers of males have been screened and yet there are very few reports of a significant percentage of fragile sites being found in someone who is intellectually and psychologically normal. The family reported by Daker et al. (1981) was apparently entirely normal. The male described by Webb et al. (1981) suffered abnormal behaviour ascribed to shell shock, and other examples of boys with normal IQs were ascertained because they had autism. It is important to emphasize, however, that fragile $\mathrm{X}$ syndrome families may contain phenotypically normal males who have transmitted the Martin-Bell syndrome to grandchildren, but these normal transmitting males do not appear to have fragile sites (Froster-Iskenius et al., 1984).

Females It has been estimated that, overall, about $30 \%$ of female heterozygotes show intellectual impairment (Turner et al., 1980), although the degree of mental retardation is on average less than in hemizygous males. However, the occasional female can have severe mental retardation even more marked than an affected brother. Nearly all mentally retarded females in proven fragile $\mathrm{X}$ syndrome families show fragile sites (Turner \& Jacobs, 1983) with the percentage of lymphocytes exhibiting fragile sites being in the $5-50 \%$ range, and on average not much less than in affected brothers. Within female sibships that include a mentally retarded female, there is no overall correlation of the percentage of fragile sites with IQs, although an inverse correlation does emerge when one relates the percentage of fragiles sites on the active $X$ chromosome to IQ (Paul et al., 1984). The absence of the fragile site can either mean the $\mathrm{X}$ chromosome does not carry the definitive Martin-Bell mutation or that metabolic conditions in the cell do not allow expression of the fragile site. Overall, only about $50 \%$ of obligate carriers show fragile sites and this makes genetic counselling difficult.

\section{Inheritance and genetic mechanisms}

Until recently the Martin-Bell syndrome was regarded as a regular X-linked condition with manifestations in a proportion of female heterozygotes. Indeed, the complex segregation analysis used by Sherman and colleagues (Sherman et al., 1984, 1985) assumes classical X-linked inheritance. However, the original Martin-Bell pedigree showed transmission through two males 'reported to be normal' and by the end of 1983 there were eight pedigrees reported showing a total of 15 phenotypically normal transmitting males, plus another inferred from linkage data (Pembrey et al., 1985), a most unlikely situation for a regular Xlinked condition where, overall, one third of female heterozygotes are intellectually impaired (Turner $e t$ al., 1980). Simple inspection of these pedigrees (Pembrey et al., 1985) revealed that the 47 daughters of these normal transmitting males represented a special class of heterozygotes for they were not mentally retarded and had either no fragile sites or very few indeed. Furthermore, when these authors (Pembrey $e t$ $a l .$, 1985) selected pedigrees from the literature that might represent transmission from a normal male (because they had at least two daughters who were obligate heterozygotes on pedigree grounds and no affected sons), they found a similar situation. These 16 normal men had 67 daughters and only one was reported as dull. It therefore has to be concluded that there are many more normal transmitting males than meets the eye, and pooling all pedigrees for the purpose of obtaining figures for genetic counselling is a waste of time, and may indeed give erroneous results. One would also expect segregation analysis of pooled data based on regular X-linked inheritance to give bizarre results, which is the case. Sherman and colleagues $(1984,1985)$ find a $20 \%$ deficit of affected males, that new mutations seem entirely confined to sperm, and that the mutation rate in sperm must be of the order of $7.2 \times 10^{-4}$, by far the highest rate recorded in mammals.

Analysis of pedigrees containing normal transmitting males suggests that what these men have inherited and transmit to their daughters is a premutation namely, a change in the DNA that causes no harm per $s e$, but predisposes to the definitive Martin-Bell mutation. Furthermore, the fact that the daughters of these normal transmitting males do not have mental retardation but their grandsons and granddaughters often do, indicates that the definitive mutation is only generated in ova. This in turn suggests that interaction between both $\mathrm{X}$ chromosomes is required to generate the definitive mutation, a recombination event being one, and perhaps the most likely, candidate (Pembrey et al., 1985). Clearly the interaction of the $X$ chromosome varies between females, because the mothers of normal transmitting males rarely have affected children, whilst the daughters of such males often do. This means that if this variability is inherent in the $\mathrm{X}$ chromosomes themselves, there must be a minimum of four types of $\mathrm{X}$ chromosome; premutation, an $\mathrm{X}$ that interacts with the premutation (probably the normal $\mathrm{X}$ ), one that cannot interact with the 
premutation, and the definitive Martin-Bell mutation. It is by no means proven that recombination events are responsible for generating these different $\mathrm{X}$ chromosomes, but models can be constructed that are potentially testable by the use of linked DNA probes.

\section{Linkage studies}

Physical mapping of genes and specific DNA sequences with respect to the fragile site at Xq27.3 have exploited the fact that the presence of the fragile site actually enhances the resolution of in situ hybridization. The gene for G6PD (Szabo et al., 1984) and the polymorphic DNA probe, St 14 (Mattei et al., 1985), have been cytologically mapped to Xq28, distal to the fragile site, and since the factor VIII gene and the probe, DX13, are very closely linked to St14 (Gitschier et al., 1985), this places these at Xq28. The factor IX gene and probe 52A map to Xq27 centromeric to the fragile site (Mattei et al., 1985).

With the exception of G6PD (which reveals a protein polymorphism), all the above probes reveal common restriction fragment length polymorphisms, and are therefore useful DNA markers for linkage studies within families.

There were early claims that linkage to factor IX was close enough to be clinically useful (Camerino et al., 1983), but these have not been substantiated (Davies et al., 1985). More closely linked probes will be needed before direct DNA analysis can supplement cytogenetic studies for carrier detection and prenatal diagnosis.

\section{Rare deletions or translocations involving the $\mathrm{X}$ chromosome}

Paediatricians may, once or twice in a lifetime, come across extraordinary experiments of nature, where a single child appropriately investigated will provide insight into basic mechanisms. There are at least two situations involving the $\mathrm{X}$ chromosome.

Rarely children are seen with more than one Xlinked disease and this should always raise the suspicion of a deletion either detectable by cytogenetic analysis or submicroscopic and therefore only detectable with X-specific DNA probes.

In 1980, Guggenheim et al. reported glycerol kinase deficiency in two boys with adrenal hypoplasia, mental retardation and neuromuscular problems, which on muscle biopsy were histologically compatible with Duchenne muscular dystrophy. Renier and colleagues (1983) have described 3 male sibs with the same spectrum of disease. One link between these apparently diverse phenotypes is the X-linked inheritance. Pseudohypertriglyceridaemia (Rose \& Haines, 1978), congenital adrenal hypoplasia (Hay et al., 1981; Hensleigh et al., 1978) and Duchenne muscular dystrophy are all inherited as X-linked recessives. Bartley et al. (1982) noted the concordance of X-linked glycerol kinase deficiency with $\mathrm{X}$-linked congenital adrenal hypoplasia in their studies of two families, but were unable to detect any abnormalities on chromosome studies. More recently, Hammond et al. (1985) reported a male infant with glycerol kinase deficiency, adrenal hypoplasia and another X-linked condition, ornithine carbamoyl transferase deficiency (OCT) (ornithine transcarbomylase deficiency, OTC, EC 2.1.3.3) who had a deletion on the short arm of the $\mathrm{X}$ chromosome. Dunger et al. (in preparation) have reported two unrelated boys who have glycerol kinase deficiency, adrenal hypoplasia, mental retardation and muscular dystrophy. In one of these boys they were able to detect a deletion on the $\mathrm{X}$ chromosome by direct analysis using the probe 754 even though a deletion was not visible by ordinary cytogenetic analysis. Such cases are likely to prove very useful in pinpointing the Duchenne muscular dystrophy locus and allowing this important gene to be cloned.

The first hint that the Duchenne muscular dystrophy locus was on the short arm of the $\mathrm{X}$ chromosome at p21 came from the rare cases of girls with the full clinical features of Duchenne muscular dystrophy. Several such cases had an X:autosome translocation (Greenstein et al., 1977; Zatz et al., 1981) and although the autosome involved varied, the breakpoint on the $X$ was always at $\mathrm{Xp} 21$. It seems that the normal $\mathrm{X}$ chromosome becomes inactive in all cells, and the translocated $\mathrm{X}$ chromosome has the normal gene at the Duchenne muscular dystrophy locus disrupted by the translocation.

Localization of the Hunter gene locus to the long arm of the $X$ chromosome came from a girl with Hunter's disease who carried an X:5 translocation (Mossman et al., 1983).

\section{References}

BARTLEY, J.A., MILLER, D.K., HAYFORD, J.T., HAYFORD, J.I. \& MCCABE, E.R.B. (1982). Concordance of X-linked glycerol kinase deficiency with X-linked congenital adrenal hypoplasia. Lancet, ii, 733.

BLOMQUIST, H., K:SON, GUSTAVSON, K.-H., HOLMGREN,

G., NORDENSON, I. \& SWEINS, A. (1982). Fragile site X chromosomes and $\mathrm{X}$-linked mental retardation in severely retarded boys in a northern Swedish county. A prevalence study. Clinical Genetics, 21, 209.

BLOMQUIST, H., K:SON, GUSTAVSON, K.-H., HOLMGREN, 
G., NORDENSON, I. \& PALSSON-STRAE, U. (1983). Fragile $\mathrm{X}$ syndrome in mildly mentally retarded children in a Northern Swedish county. A prevalence study. Clinical Genetics, 24, 393.

BLOMQUIST, H., K:SON, BOHMAN, M., EDVINSSON, S.O., GILLBERG, C., GUSTAVSON, K.-H., HOLMGREN, G. \& WAHLSTROM, J. (1985). Frequency of the fragile $\mathbf{X}$ syndrome in infantile autism. Clinical Genetics, 27, 113.

BROOKWELL, R. \& TURNER, G. (1983). High resolution banding and the locus of the $\mathrm{Xq}$ fragile site. Human Genetics, 63, 77.

BROWN, W.T., FRIEDMAN, E., JENKINS, E.C., BROOKS, J., WISNIEWSKI, K., RAGUTHU, S. \& FRENCH, J.H. (1982). Association of fragile $\mathrm{X}$ syndrome with autism. Lancet, $\mathrm{i}$, 100.

BUHLER, E.M. \& MALIK, N.J. (1984). Invited Editorial Comment. The tricho-rhino-phalangeal syndrome(s): Chromosome 8 long arm deletion: is there a shortest region of overlap between reported cases? TRP I and TRP II syndromes: are they separate entities? American Journal of Medical Genetics, 19, 113.

BUNDEY, S., WEBB, T.P., THAKE, A. \& TODD, J. (1985). A community study of severe mental retardation in the West Midlands and the importance of the fragile X chromosome in its aetiology. Journal of Medical Genetics, 22, 258.

CAMERINO, G., MATTEI, M.G., MATTEI, J.F., JAYE, M. \& MANDEL, J.L. (1983). Close linkage of fragile X-mental retardation syndrome to haemophilia $B$ and transmission through a normal male. Nature, 306, 701.

CASPERSSON, T., ZECH, L. \& JOHANSSON, C. (1970). Analysis of the human metaphase chromosome set by aid of DNA-binding fluorescent agents. Experimental Cell Research, 62, 490.

DAVIES, K.E., MATTEI, M.G., MATTEI, J.F., VEENEMA, H., MCGLADE, S., HARPER, K., TOMMERUP, N., NIELSEN, K.B., MIKKELSEN, M., BEIGHTON, P., DRAYNA, D., WHITE, R. \& PEMBREY, M.E. (1985). Linkage studies of Xlinked mental retardation: high frequency of recombination in the telomeric region of the human $\mathrm{X}$ chromosome. Human Genetics, 70, 249.

DOBYNS, W.B., STRATTON, R.F. \& GREENBERG, F. (1984). Syndromes with lissencephaly. 1: Miller-Dieker and Norman-Roberts syndromes and isolated lissencephaly. American Journal of Medical Genetics, 18, 509.

DOBYNS, W.B., STRATTON, R.F., PARKE, J.T., GREENBERG, F., NUSSBAUM, R.L. \& LEDBETTER, D.H. (1983). MillerDieker syndrome and monosomy $17 \mathrm{p}$. Journal of Pediatrics, 102, 552.

DAKER, M.G., CHIDIAC, P., FEAR, C.N. \& BERRY, A.C. (1981). Fragile $X$ in a normal male: a cautionary tale. Lancet, $\mathbf{i}, 780$.

DUNGER, D.B., DAVIES, K.E., PEMBREY, M.E., LAKE, B.D., PEARSON, P., WILLIAMS, D., WHITFIELD, A. \& DILLON, M.J.D. (1985). A deletion on the X chromosome detected by direct DNA analysis, in one of two unrelated boys with glycerol kinase deficiency, adrenal hypoplasia and Duchenne muscular dystrophy.

DUNN, H.G.. RENPENNING, H., GERRARD. J.W.. MILLER. J.R., TABATA, T. \& FEDEROFF, S. (1963). Mental retardation as a sex-linked defect. American Journal of Mental Deficiency, 67, 827.

EDWARDS, J.H., HARNDEN, D.G., CAMERON, A.H., CROSSE, V.M. \& WOLFF, O.H. (1960). A new trisomic syndrome. Lancet, i, 787.

FERRELL, R.E. \& RICCARDI, V.M. (1981). Catalase levels in patients with aniridia and/or Wilms' tumor: utility and limitations. Cytogenetics and Cell Genetics, 31, 120.

FISHBURN, J., TURNER, G., DANIEL, A. \& BROOKWELL, R. (1983). The diagnosis and frequency of $X$-linked conditions in a cohort of moderately retarded males with affected brothers. American Journal of Medical Genetics, 14, 713.

FITCHETT, M. \& SEABRIGHT, M. (1984). Deleted X chromosomes in patients with the fragile $\mathrm{X}$ syndrome. Journal of Medical Genetics, 21, 373.

FOLSTEIN, S. \& RUTTER, M. (1977). Infantile autism: A genetic study of 21 twin pairs. Journal of Child Psychology and Psychiatry, 18, 297.

FRANCKE, U., GEORGE, D.L., BROWN, M.G. \& RICCARDI, V.M. (1977). Gene dosage effect: intraband mapping of the LDHA locus using cells from four individuals with different interstitial deletions of 11. Cytogenetics and Cell Genetics, 19, 197.

FROSTER-ISKENIUS, U., FELSCH, G., SCHIRREN, C. \& SCHWINGER, E. (1983). Screening for $\mathrm{fra}(\mathrm{X})(\mathrm{q})$ in a population of mentally retarded males. Human Genetics, 63, 153.

FROSTER-ISKENIUS, U., SCHULZE, A. \& SCHWINGER, E. (1984). Transmission of the marker $X$ syndrome trait by unaffected males: conclusions from studies of large families. Human Genetics, 67, 419.

FRYNS, J.P., JACOBS, J., KLECZKOWSKA, A. \& VAN DEN BERGHE, H. (1984). The psychological profile of the fragile X syndrome. Clinical Genetics, 25, 131.

GILLBERG, C. (1983). Identical triplets with infantile autism and the fragile X syndrome. British Journal of Psychiatry? 143, 256.

GITSCHIER, J., DRAYNA, D., TUDDENHAM, E.G.D., WHITE, R.L. \& LAWN, R.M. (1985). Genetic mapping and diagnosis of haemophilia A achieved through a BclI polymorphism in the factor VIII gene. Nature, 314, 738.

GLOVER, T.W. (1983). In Cytogenetics of the Mammalian $X$ Chromosome Part B, Sandberg, A.A. (ed). p. 415. A.R. Liss Inc: New York.

GREENSTEIN, R.M., REARDON, M.P. \& CHAN, T.S. (1977). An $\mathrm{X}$ /autosome translocation in a girl with Duchenne muscular dystrophy (DMD). Evidence for DMD gene localization (abstract). Paediatric Research, 11, 457.

GUGGENHEIM, M.A., MCCABE, E.R., ROIG, M., GOODMAN, S.I., LUM, G.H., BULLEN, W.W. \& RINGEL, S.P. (1980) Glycerol kinase deficiency with neuromuscular, skeletal and adrenal abnormalities. Annals of Neurology, 7, 441.

HAMERS, A., JONGBLOET, P., PEETERS, G. \& GERAEDTS, J. (1983). Microcytogenetics of chromosome 8q. Poster presented at the 8th International Chromosome Conference, Lubeck. September (abstract 2-8).

HAMMOND, J., HOWARD, N.T., BROOKWELL, R., PURVISSMITH, S., WILCKEN, B. \& HOOGENRAAD, N. (1985). Proposed assignment of loci for X-linked adrenal hypoplasia and glycerol kinase deficiency. Lancet, i, 54.

HAY, I.D., SMAIL, P.J. \& FORSYTH, C.C. (1981). Familial cytomegalic adrenocortical hypoplasia: an X-linked syndrome of pubertal failure. Archives of Disease in Childhood, 56, 715.

HENSLEIGH, P.A., MOORE, W.V., WILSON, K. \& TULCHINSKY, D. (1978). Congenital X-linked adrenal hypoplasia. Obstetrics and Gynaecology, 52, 228. 
HOWARD-PEEBLES, P.N. \& FINLEY, W.H. (1983). Screening of mentally retarded males for macro-orchidism and the fragile X chromosome. American Journal of Medical Genetics, 15, 631.

JACOBS, P.A., MAYER, M., MATSUURA, J., RHOADS, F. \& YEE, S.C. (1983). A cytogenetic study of a population of mentally retarded males with special reference to the marker (X) syndrome. Human Genetics, 63, 139.

JOHNSON, M.P., RAMSAY, N., CERVENKA, J. \& WANG, N. (1982). Retinoblastoma and its association with a deletion in chromosome 13: a survey using high resolution chromosome techniques. Cancer Genetics and Cytogenetics, 6, 27.

LANGER, L.O., KRASSIKOFF, N., LAXOVA, R., SCHEERWILLIAMS, M., LUTTER, L.D., GORLIN, R.J., JENNINGS C.G. \& DAY, D.W. (1984). The tricho-rhino-phalangeal syndrome with exostoses (or Langer-Giedion syndrome). American Journal of Medical Genetics, 19, 81 .

LARGO, R.H. \& SCHINZEL, A. (1985). Developmental and behavioural disturbances in 13 boys with fragile $X$ syndrome. European Journal of Pediatrics, 143, 269.

LEDBETTER, D.H., RICCARDI, V., AIRHART, S.D., STROBEL, R.J., KEENAN, B.S. \& CRAWFORD, J.D. (1981). Deletions of chromosome 15 as a cause of Prader-Willi syndrome. New England Journal of Medicine, 304, 325.

LEJEUNE, J.H. (1959). Le Mongolisme. Premier exemple d'aberration autosomique humaine. Annals of Genetics, 1 , 41.

LEVITAS, A., HAGERMAN, R.J., BRADEN, M., RIMLAND, B., MCBOGG, P. \& MATUS, I. (1983). Autism and the fragile X syndrome. Journal of Developmental and Behavioural Paediatrics, 4, 151.

MARTIN, J.P. \& BELL, J. (1943). A pedigree of mental defect showing sex-linkage. Journal of Neurology, Neurosurgery and Psychiatry, 6, 154.

MATTEI, M.G., BAETEMAN, M.A., HEILIG, R., OBERLE, I., DAVIES, K., MANDEL, J.L. \& MATTEI, J.F. (1985). Localization by in situ hybridization of the coagulation factor IX gene and of two polymorphic DNA probes with respect to the fragile X site. Human Genetics, 69, 327.

MERYASH, D.L., CRONK, C.E., SACHS, B. \& GERALD, P.S. (1984). An anthropometric study of males with the fragile$\mathrm{X}$ syndrome. American Journal of Medical Genetics, 17, 159.

MOSSMAN, J., BLUNT, S., STEPHENS, R., JONES, E.E. \& PEMBREY, M. (1983). Hunter's disease in a girl: association with X:5 chromosomal translocation disrupting the Hunter gene. Archives of Disease in Childhood, 58, 911.

NAKAGOME, Y., ISE, T., SAKURAI, M., NAKAJO, T., OKAMOTO, E., TAKANO, T., NAKAHORI, Y., TSUCHIDA, Y., NAGAHARA, N., TAKADA, Y., OHSAWA, Y., SAWAGUCHI, S., TOYOSAKA, A., KOBAYASHI, N., MATSUNAGA, E. \& SAITO, S. (1984). High resolution studies in patients with aniridia-Wilms' tumour association, Wilms' tumor or related congenital abnormalities. Human Genetics, 67, 245.

NUSSBAUM, R.L., AIRHART, S.D. \& LEDBETTER, D.H. (1983). Expression of the fragile (X) chromosome in an interspecific somatic cell hybrid. Human Genetics, 64, 148.

OPITZ, J.M., WESTPHAL, J.M. \& DANIEL, A. (1984). Discovery of a connective tissue dysplasia in the Martin-Bell syndrome. American Journal of Medical Genetics, 17, 101.

OPITZ, J.M. \& SUTHERLAND, G.R. (1984). Conference Report: International Workshop on the Fragile X and X- linked Mental Retardation. American Journal of Medical Genetics, 17, 5.

ORKIN, S.H., GOLDMAN, D.S. \& SALLEN, S.E. (1984). Development of homozygosity for chromosome $11 \mathrm{p}$ markers in Wilms' tumour. Nature, 309, 172.

PATAU, K., SMITH, D.W., THERMAN, E., INHORN, S.L. \& WAGNER, H.P. (1960). Multiple congenital anomaly caused by an extra autosome. Lancet, i, 790.

PAUL, J., FROSTER-ISKENIUS, U., MOJE, W. \& SCHWINGER, E. (1984). Heterozygous female carriers of the marker-Xchromosome: IQ estimation and replication status of fra(X)(q). Human Genetics, 66, 344.

PEMBREY, M.E., WINTER, R.M. \& DAVIES, K.E. (1985). A premutation that generates a defect at crossing over explains the inheritance of fragile $\mathbf{X}$ mental retardation. American Journal of Medical Genetics, 21, 709.

PUESCHEL, S.M. \& FINELLI, P.V. (1985). Neurological investigations in patients with fragile-X syndrome. $D e$ velopmental Medicine and Child Neurology, 27, 95.

RENIER, W.O., NABBEN, F.A.E., HUSTINX, T.W.J., VEERKAMP, J.H., OTTEN, B.J., TER LAAK, H.J., TER HAAR, B.G.A. \& GABREELS, F.J.M. (1983). Congenital adrenal hypoplasia, progressive muscular dystrophy, and severe mental retardation, in association with glycerol kinase deficiency, in male sibs. Clinical Genetics, 24, 243.

RICHARDS, B.W., SYLVESTER, P.E. \& BROOKER, C. (1981). Fragile X-linked mental retardation: the Martin-Bell syndrome. Journal of Mental Deficiency Research, 25, 253.

ROSE, C.I. \& HAINES, D.S.M. (1978). Familial hyperglycerolaemia. Journal of Clinical Investigation, 61, 163.

SHERMAN, S.L., MORTON, N.E., JACOBS, P.A. \& TURNER, G. (1984). The marker (X) syndrome: a cytogenetic and genetic analysis. Annals of Human Genetics, 48, 21.

SHERMAN, S.L., JACOBS, P.A., MORTON, N.E., FROSTERISKENIUS, U., HOWARD-PEEBLES, P.N., NIELSEN, K.B., PARTINGTON, M.W., SUTHERLAND, G.R., TURNER, G. \& WATSON, M. (1985). Further segregation analysis of the fragile $X$ syndrome with special reference to transmitting males. Human Genetics, 69, 289.

SOUDEK, D., PARTINGTON, M.W. \& LAWSON, J.S. (1984). The fragile $X$ syndrome I: Familial variation in the proportion of lymphocytes with the fragile site in males. American Journal of Medical Genetics, 17, 241.

SUTHERLAND, G.R. (1977). Fragile sites on human chromosomes: Demonstration of their dependence of the type of tissue culture medium. Science, 197, 265.

SUTHERLAND, G. (1982). Heritable fragile sites on human chromosomes. VIII. Preliminary population cytogenetic data on the folic-acid-sensitive fragile sites. American Journal of Human Genetics, 34, 452.

SUTHERLAND, G.R. (1985). The enigma of the fragile $X$ chromosome. Trends in Genetics, 1, 108.

SZABO, P., PURRELLO, M., ROCCHI, M., ARCHIDIACONO, N., ALHADEFF, B., FILIPPI, G., TONIOLO, D., MARTINI, G. \& LUZZATTO, L. (1984). Cytological mapping of the human glucose-6-phosphate dehydrogenase gene distal to the fragile- $X$ site suggests a high rate of meiotic recombination across this site. Proceedings of the National Academy of Sciences of the USA, 81, 7855.

THAKE, A., TODD, J., BUNDEY, S. \& WEBB, T. (1985). Is it possible to make a clinical diagnosis of the fragile-X syndrome in a boy? Archives of Disease in Childhood, 60, 1001. 
TOMMERUP, N., SONDERGAARD, F., TONNESEN, T., KRISTENSEN, M., ARVEILER, B. \& SCHINZEL, A. (1985). First trimester prenatal diagnosis of a male fetus with fragile $\mathbf{X}$. Lancet, i, 870.

TURNER, G., BROOKWELL, R., DANIEL, A., SELIKOWITZ, M. \& ZILIBOWITZ, M. (1980). Heterozygous expression of $\mathrm{X}$-linked mental retardation and X-chromosome marker $\mathrm{fra}(\mathrm{X})(\mathrm{q} 27)$. New England Journal of Medicine, 303, 662.

TURNER, G. \& JACOBS, P. (1983). Marker (X)-linked mental retardation. In Advances in Human Genetics, Harris H. and Hirschnorn, K. (eds). p. 83. Plenum Press: New York.

VENTER, P.A., OP'T HOF, J., COETZEE, D.J., VAN DER WALT, C. \& RETIEF, A.E. (1984). No marker (X) syndrome in autistic children. Human Genetics, 67, 107.

VOGEL, F. (1979). Genetics of retinoblastoma. Human Genetics, 52, 1.
WEBB, G., ROGERS, J.G., PIH, D.B., HALLIDAY, J. \& THEOBALD, T. (1981). Transmission of fragile Xq27 site from a male. Lancet, ii, 1231.

YUNIS, J.J. (1976). High resolution of human chromosomes. Science, 191, 1268.

YUNIS, J.J. \& LEWANDOWSKI, R.C. (1983). High-resolution cytogenetics. Birth Defects: Original Article Series, 19, 5 : 11.

ZATZ, M., VIANNA-MORGENTA, A.M., CAMPOS, P. \& DIAMENT, A.J. (1981). Translocation $(X ; 6)$ in a female with Duchenne muscular dystrophy: implications for the localisation of the DMD locus. Journal of Medical Genetics, 18, 442. 